\title{
Tolerance of Islam: A Study on Fashion among Modern and Professional Malay Women in Malaysia
}

\author{
Hanisa Hassan, Biranul Anas Zaman, and Imam Santosa
}

\begin{abstract}
Malay women in Malaysia had evolved from traditional to the modern lifestyle that witnessed changes in perception, action and artifacts for the past hundreds of years. Malay position in the society had changed from being a mere housewife to a career oriented women. Cultural changes had transformed Malay women's appearance especially on clothing. Facing a dilemma to look religious and professional at the same time is not an easy task. Modern women has to face the fact that they need to look fashionable but at the same time abiding Islamic regulation by not to display their beauty. This descriptive research is to look at how Malay women in Malaysia negotiate their style of clothing with urban culture and on top of that, following the guideline of clothing in Islam. Data derived were mainly from observation and interviews. Findings will be valuable for future research on designing dedicated to Muslim women across the globe.
\end{abstract}

Index Terms-Malays, Malaysia, Muslim fashion.

\section{INTRODUCTION}

Malays in Malaysia are proclaimed as Muslim, as stated in the Constituent of Malaya (Act 160 (2) after the independence of Malaysia in 1957. Being Malay also means that they need to carry common duties as Muslim at the same time. Muslim women in Malaysia however are more fortunate compared to their sisters where women are still a second class citizen in a few Middle Eastern countries. Malay women in Malaysia a free to further their studies choose their own career path and even marry anyone they prefer. These phenomena had come a long way before, as in the past women only held domestic role as housewife; working class woman is almost nonexistent. Working and earning money among women were made possible when British occupied Malaya (Malaysia), starting from the late 1900s. Profession like teachers, nurses or clerk were made accessible by Malay women especially in bigger towns like Kuala Lumpur, Penang or Ipoh.

Slowly, when Malaysia had their independence in 1957, the government realized that social revamp is needed due to unequal wealth distribution among races. In 1970s, the government introduced new economic plan (NEP) to boost the country's economy, by sending more Malays to study abroad. In late 1970s many Malay professionals came back to Malaysia and work for the government and also for private

Manuscript received January 15, 2014; revised March 18, 2014.

Hanisa Hassan and Imam Santosa are with the Bandung Institute of Technology (ITB), Indonesia (e-mail: hanisa74@gmail.com, imamz@fsrd.itb.ac.id).

Biranul Anas Zaman is with the Faculty of Design at University of Computer Indonesia (UNIKOM) in Bandung, Indonesia (email: biranul@yahoo.com). sectors. Migration of Malays from rural areas to bigger cities like Kuala Lumpur (KL), Penang, and Johor Bahru (JB) had created new phenomena that created urban Malay society. The new 'form' of Malay had created new identity and culture that can be witnessed through cultural object such as clothing.

Being an urban society has its price. One has to cope with peer pressure, demanding expectation from workplace, professionalism and multicultural environment that need them to tolerate their belief, culture or ideology. Urban Malay women are mostly well educated and earning on their own is a common phenomenon nowadays. Women are given the chance to excel in their work field like men do. But as for Malay women, living a life as an urban citizen does not signify total freedom. One still has to abide to what they belief, which is faith on Islam. Certain things such as appearance are still very much religion oriented. Clothing is a form of cultural object derived from these two systems which are belief and act of living.

An urban Muslim woman have to think on how to confront the multi-racial environment which culture differs from their previous lifestyle; whereby sarong and faded blouse are acceptable by the society. Once they are in the urban setting, they need to cope with new standard of living whereby appearance is becoming important. Facing the new diverse setting makes them change their visual appearance to a more global style via clothing. Negotiation on these matters on daily basis makes them perceive things in a different way. New values were developed as a result of tolerance in order to survive the 'new culture'. This research is to see, how modern women tolerate their belief and practice them in their daily urban environment. Clothing will be the object of study by looking at the tolerance level between Islam and styling among Malay woman.

\section{THEORIES}

The existence of culture theory mentioned that culture can be evidenced through three forms. According to J. J Honingmann they are ideas, activities and artifacts. Koentjananingrat also mentioned that the forms are custom (values or norm), social and artifacts/ cultural objects [1]. The first form which is idea cannot be seen but very important as it will transform the values, norm, characteristics and belief that can be influenced within contact of other culture or internally. Diffusion with other culture may come in various forms like media or experiencing other culture outside one's boundary. The transmission will soon absorbed the social system that will changed once attitude, social system, religion, political 
administration, interaction or expression that can be observed by others. Cultural object derived from both forms, whereby human show adaptation or changes onto something that can be held and concrete.

Clothing changes as a result of transformation in form of idea and activities in certain community. Flugel in his theory mentioned, fashion change are contributed by "ambivalence specifically that generated through the psychic clash of modesty and display, as the main mover in fashion change". [2]. Muslim women in urban areas are having this clashes that made them transformed their cultural object to something more global rather than racial related clothing.

Since being Malay in Malaysia means being a Muslim, women have to display their faith through clothing. A Muslim must not distinguish oneself like the non-Muslim way of clothing which by enhancing their body. As Flugel mentioned, new designs had developed due to the clash of modesty and display. There are about 500 verses from Al-Quran and more in hadith regarding women's clothing that Muslim women need to follow, such as one below.

"Oh Prophet! Tell your wives, your daughters and the women of the believers (of Islam) to let down upon themselves their jalabib $\left(\right.$ jilbab $\left.^{2}\right)$. That will be better, and that they should be known as respectable woman, so as not to be disturbed. And Allah is ever Oft-Forgiving, Most Merciful" (Al-Ahzaab, 33:59)

Basically, the regulation written in Al-Quran and hadith, are meant to protect women from harm. Some of the major guidelines can be summarized to Table 1 as follows:

Despite the guidelines written in the holy book of Al-Quran and explained in many examples through Hadith, Islam never put a specific form of design for Muslims to abide. The guideline is rather general but having specific instruction for Muslims to follow. So there is opportunity for Muslim women to interpret the guidelines according to their culture, climate or activity, as long as it stays within the instruction given.

Most modern Muslim women in Malaysia have the opportunity to further their study to any level as they wish, own their living and choose their life partner, which are unlikely during the traditional era [3]. But living in a modern age has its challenges, whereby being professionally noticeable, respectable and presentable have become an obligation in today's working-class culture. By living in urban environment, Muslim women in Malaysia are basically caught up with the clash as mentioned by Flugel. Besides having to comply with the guidelines provided for Muslim women, they also need to look stylish and presentable in public. Being perceived as professionals in the modern age require a woman to look modern and global; as mentioned by Giddens; "Being modern is about being global" [4].

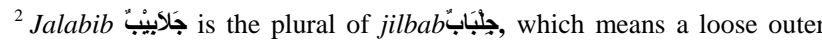
garment. See any Arabic dictionary like Lisanu 'l-'Arab, Majma ' $u$ 'l-Bahrayn or al-Munjid. Al-Munjid, for instance, defines jilbab as

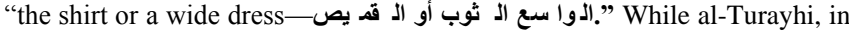
Majma' $u$ 'l-Bahrayn, defines it as "a wide dress, wider than the scarf and shorter than a robe that a woman puts upon her head and lets it down on her bosom. Source: http://www.al-islam.org/hijab-muslim-womens-dress-islamic-or-cultural-sa yyid-muhammad-rizvi/qur\%E2\%80\%99-and-hijab (29.10.13)
}

TABLE I: FUNDAMENTAL GUIDELINES IN ISLAMIC CLOTHING FOR MUSLIM WOMEN

\begin{tabular}{|c|c|}
\hline Guideline & Rationale \\
\hline $\begin{array}{l}\text { Garment must cover the whole body } \\
\text { from unpermitted man } \\
(\text { non-mahram) }\end{array}$ & \multirow{5}{*}{$\begin{array}{l}\text { All the rules basically tell the } \\
\text { Muslim women not to expose their } \\
\text { body shape or form in any manner } \\
\text { as it may draw attention of men. } \\
\text { Albeit not all men have nasty } \\
\text { desire towards women, but the } \\
\text { guideline is made for prevention. }\end{array}$} \\
\hline $\begin{array}{l}\text { Dress must not be transparent or } \\
\text { semi transparent }\end{array}$ & \\
\hline $\begin{array}{l}\text { Dress must not be tight fitting that } \\
\text { will resembles the body shape }\end{array}$ & \\
\hline $\begin{array}{l}\text { Not to use strong perfume until it } \\
\text { will draw attention of others }\end{array}$ & \\
\hline $\begin{array}{l}\text { Not to show off their jewellery or } \\
\text { even make indication of it (like } \\
\text { sound from a bell) as it may led to } \\
\text { larceny. }\end{array}$ & \\
\hline $\begin{array}{l}\text { Not to dress like non-believer (by } \\
\text { not covering their } \text { aurat }^{4} \text {. They must } \\
\text { not display act to attract men. }\end{array}$ & \multirow{2}{*}{$\begin{array}{l}\text { A Muslim woman must } \\
\text { differentiate themselves from the } \\
\text { non-believer by dressing according } \\
\text { to the guidelines; but still not } \\
\text { losing their grace as woman. }\end{array}$} \\
\hline Dress should not resemble as men & \\
\hline $\begin{array}{l}\text { Garment must not to be a form of } \\
\text { showing honour/ wealth }\end{array}$ & $\begin{array}{l}\text { Men and women should be humble } \\
\text { by not showing off their material } \\
\text { comfort or being arrogant. }\end{array}$ \\
\hline
\end{tabular}

Rationale of this study is to look at modern Muslim dilemmas, on how they tolerate fashion within the guideline of Islam in Malaysian context. Main research questions are summarized as below:

1) How do Muslim women negotiate their daily style with Islamic guidelines?

2) How does the Muslim fashion look like?

\section{Methodology}

This research is basically descriptive, with ethnographic method using qualitative approach. Since the subject is Muslim women (Malays) and the object is their attire, specific selection of respondents are chosen for this study. The criteria include; (i) those who work in professional field, educated (minimum at degree level), (ii) originated from village and migrated to bigger cities, such as Kuala Lumpur (KL). (iii) Working environment must be multi-racial to enable researcher to observe any intervention made in clothing due to such environment. (iv) Office wear will be the main research object since many thoughts has to be negotiated, such as working condition, social interaction and corporate image. (v) Location of the respondents were public spaces such as cafés, hotels, function area, etc).

This will made possible to understand how negotiation is

\footnotetext{
${ }^{3}$ Non-Mahram or Ghayr Mahrams refers to all those males whom a woman is permitted to marry (e.g. a cousin or just a random Muslim male) or a male whom it is forbidden to marry at that moment in time but may become permissible to marry in the future due to a change in circumstances. In other word a male who is temporarily forbidden (e.g. a Muslim female who is already married is temporarily forbidden to marry another Muslim male as long as she is married. But once she divorces her current husband and passes her 'Iddah' (waiting period after divorce), she may now marry another Muslim male and he is no longer forbidden for her). Source http://www.islamicinformation.net/2008/07/mahram-in-islam-explained.ht $\mathrm{ml}(29.10 .13)$

${ }^{4}$ Overall schools of thoughts in Islamic fiqh have unanimously agreed that aurah for men is between their navels and knees; while for women their aurah is their whole body except for their faces and palms (based on powerful source from Quran and Sunnah). Souce http://www.islam.gov.my/en/e-hadith/aurah-amongst-men-and-women $(9.10 .13)$
} 
made between the guidelines of Islam and modern issues that a woman has to face in daily. However, respondent's company must not provide uniform as this will refrain them from styling. Observation on the streets is also conducted to generalize the style among Muslim women in Malaysia that was done at urban areas such as Kuala Lumpur. Data was evaluated using descriptive analysis in connecting social change to the cultural object (clothing).

\section{DISCUSSIONS}

Respondent 1 is a deputy dean of an art school, who majors fashion during her first degree. Her hometown is in Kelantan, with the most Malay population in Malaysia. Her family migrated to Gombak (KL) when she was five years old and her father died when she was in her late 20s.

Now, she works in a private collage, dominated by Chinese. Besides teaching, she also has her sideline business as designer, consultant and running a cafe. Her hectic life needs her to wear practical clothing that made her easy to manage her busy responsibilities. Plus, being a fashion lecturer and holds a task at management level in the university made clothing significant to uphold professional image. But being a lecturer and a designer does not mean that she has to appear extrovert or over-the-top. She prefers to be humble instead.

She rarely wears traditional costumes such as baju kurung or baju kebaya ${ }^{5}$ except for functions that specify her to do so. "It's not that I don't want to, but baju kurung restrict my movements. Trousers are more versatile and comfortable to suit my busy chores." She is more comfortable in pants, loose blouse, simple scarf or shawl. She also wears long vest or wrapped shawl to cover her buttocks. She likes subtle color, as she prefers not to look extrovert in her appearance. "I love black, red and orange" she confessed. "As I may don't have a perfect body, I rather go for something loose. Even if I do have size 0 , it is not right to wear skimpy tight blouse or pants it just doesn't feels right. Perhaps the teaching of Islam made me feel uncomfortable to do so".

She is very much devoted to her religion. It is shown through her design lines which are very much dedicated to professional, urban Muslims women. She designed her own label. In her designs, she always gives option for professional women to choose their style without restricted them to just limited styles of hijab ${ }^{6}$ or abbaya. ${ }^{7}$ [5]. She always plays around with loose-tube silhouettes and layering with other

${ }^{5}$ Baju kurung and kebaya are types of traditional Malay dress for women, widely used in rural areas and as uniforms in many government offices or functions. They consist of loose tops and sarong, worn like a long skirt. Baju kurung and kebaya were made based on geometric patterns or sometimes called 'constructed pattern'. Those two types of dress are still very popular during religious event or cultural activities, such as Eid, funeral, weddings, etc.

6 "Hijab" in the dictionary we learn that the word means "veil", "screen", "cover(ing)" or "curtain" (see Al Mawrid: A Modern Arabic English Dictionary, 1992 p. 453). The meaning of the word "Hijab" becomes more clear to mean "covering" which also means "veil" as Allah I Himself uses the term. Souce: http://www.lakii.com/lakiibooks-84.html (29.10.13)

[5]Abbaya sometimes also called an $a b a$, is a simple, loose over-garment, essentially a robe-like dress, worn by some women in parts of the Muslim world including in North Africa and the Arabian Peninsula. (Yarwood, 1978)p.9 pieces to cover the bust or buttock areas using overlapping clothing or vest, shawl and cape. It makes her design looks complete without being extrovert or too eye catching. Her idea of Islamic fashion wear can be perceived on some of the below Fig. 1a)-c):

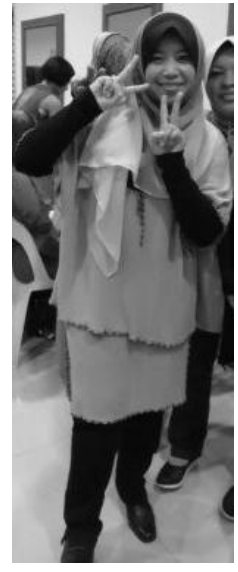

a)

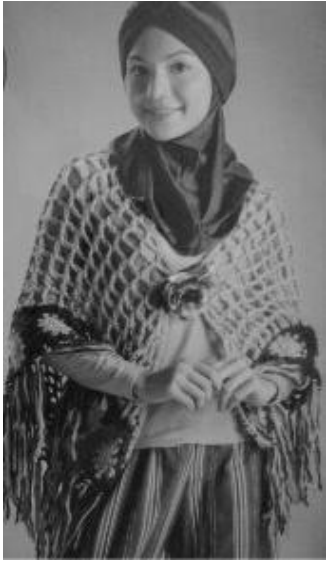

b)

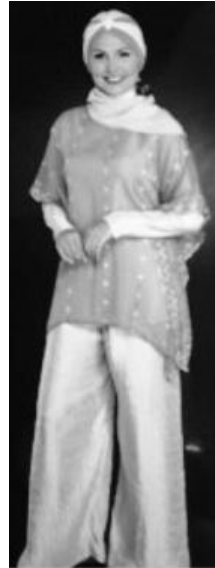

c)
Fig. 1a). Respondent in her own design. Covering her bust and buttocks with layers of fabric instead of the typical hijab (abbaya). b). Respondent's design using macramé knit as cape to cover the bust area, with loose inner blouse and pants. c). Having an inner blouse and loose tunic outside is similar to covering one's bust, as an alternative of shawl. The rest remain covered, as per Islamic guideline.

Another respondent, (respondent 2) is an English lecturer in a state-owned university. She is a modern and moderate Malay Muslim. Her hometown is in Seremban, Negeri Sembilan but now residing in Kuala Lumpur. She complies moderately with Islamic practices in her daily life, even though she is well versed on what can and cannot be worn as a Muslim woman. She started wearing a shawl recently, when she came back from umrah (visit) to Mecca last year. Before going to umrah, she dressed freely, without complying to the guidelines as how Muslim women should have. Nowadays, she slowly started changing her way of dressing style in her daily appearance. For a start, she covers her hair with a long shawl (selendang in Malay).

Working as a lecturer in a semi-government agency does not restrict her from styling but her superior prefers Islamic way in appearance. "I prefer blouse and skirt, but ever since I wear head scarf, I use long pants". Wearing traditional dress like baju kurung or kebaya is also a familiar choice in her wardrobe. "My campus is hot, so I can't wear jacket to cover my short sleeve blouse. So I would opt to wear traditional dress or long-sleeved blouse with pants." "To me, guideline is foremost important, whether it's religion-based or company rules, subsequently practicality and respecting others. Fashion appeared came second last since I don't have the privilege to be fashionable due to my remote setting and monotony scope of job. But most importantly- one needs to dress appropriately to respect others despite what we believe in." She is not comfortable with short skirt worn by her non-Muslim colleagues as she finds it inappropriate in a formal setting, especially in Malaysian context. "Even though I sometime wear sleeveless or short sleeved blouse, I tend to cover my arms with a long sleeved outer blouse." She also does not mind wearing shaped outfit as long as it not too tight fitting or reveal too much of her skin as she finds it 
inappropriate. Having darts on certain garments proportioned one's body, as she feels more presentable and confident. "I never put a dress intended to attract men when going out to work. That is so lame, I believe in complying to the guideline and looking professional at workplace," she added.

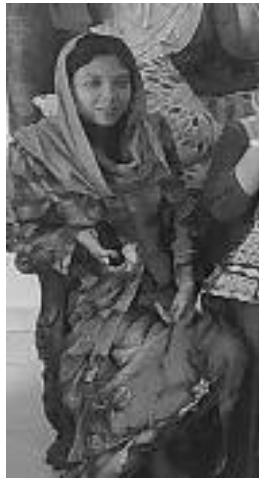

a)

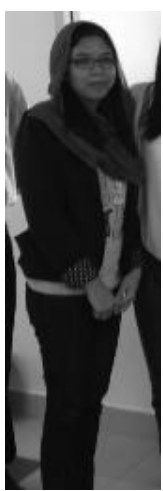

b)

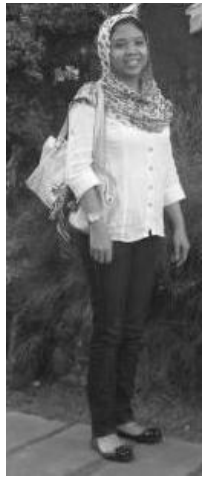

Fig. 2a). Picture of respondent in baju kurung and shawl. b). Respondent with her more casual look, with a jacket-shirt, jeans and a shawl. c). Respondent with long sleeved blouse and a shawl.

Respondent 3 is a civil engineer. Her job requires her to visit construction site, meetings and running back to office to finish up her paperwork. "For that kind of work, my way of clothing depends solely on my daily working schedule. If I need to visit site, I will wear blouse and long pants, sometime loose jeans. If I just stay at the office, I would wear baju kurung or jubah (abbaya)." As someone who practices Islamic teachings, she mentioned, guidelines clothing for Muslim is up most important, followed by practicality and fashion. "As a Muslim, we have to look like one", she added. Attracting others never cross her mind. She prefers long blouse that covers her buttock. She normally wears a cardigan outside as an additional piece of her inner top consists of blouse or shirt. She also covers her bust with head scarf.

She change her style of dressing after she got married, to fitted body blouses to a rather loose sets, even though she started wearing head scarf when she was 15 . "I changed my way of dressing as to respect her husband. He will carry my sin if I dress indecently", she claimed. Even though her multi-racial company does not forbid her from wearing any style of fashion, she rather sticks to her own simple style. "I mix and match whatever fashion that I like, as long as it complies with the guidelines stated in Islam and practical for my job" she ended.

Interviews also conducted to several companies to understand their criteria of selecting a candidate; does appearance plays an important role besides their academic qualification and skills. Majority answered "yes" to that statement. Looking like Arab women may not be suitable in a multi-racial company, but it is accepted in most Malay-Muslim companies. For most private sectors led by non-Muslims, they prefer a female Malay worker who appears professional and global such as dressed in suits, mix and matched pieces or just traditional clothing. Many multi-racial companies do not mind women wearing head scarf, but not to the extent of covering the whole face as it reflects extremism.

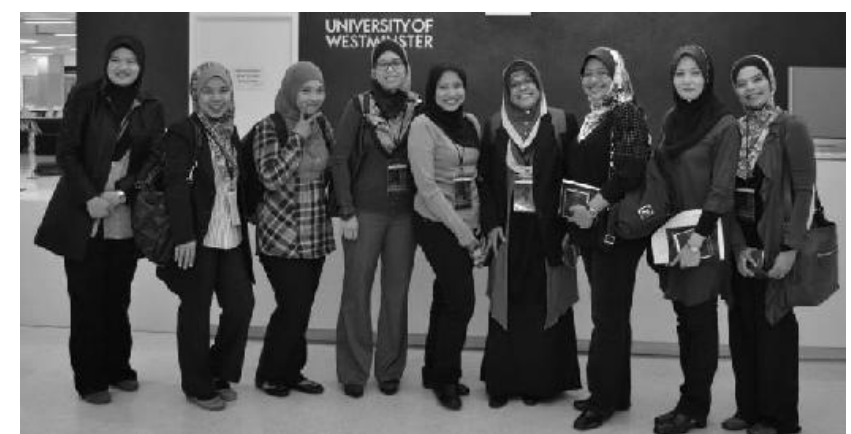

Fig. 3. Respondent in blue cardigan (right) with her colleagues who dressed properly during a seminar presentation.

\section{ANALYSIS}

As through interviews and observation, the study reveals that Malaysian women (within the category justified) understand well regarding the Islamic guidelines. Within the guideline, there are a few elements used to suit their lifestyle and modern environment, however values and religion perception may differ from those who reside in different setting. Professional, middle class Muslim women wear attires to suit their urban lifestyle and social setting, unlike from those who work in rural areas. Working professionally requires them to look presentable but practical and comfortable enough to suit their standard of living.

As basic Islamic guideline in dressing opposed women from displaying their body shape or form, working Muslim women in Malaysia prefers to play around with various pieces such as jacket or cardigan layering a blouse instead of covering the bust with shawl. The outer piece (which is mostly loose) does the same job as a shawl in covering the bust with another layer of cloth or clothing. Fashionable shawls are also used to cover the hair but not their faces as most of them followed the moderate Sunni, which is to cover everything except their face and outer palms ${ }^{8}$. As for the lower parts of the body, respondents used long skirt or trousers and sometimes with sarong (only if worn with traditional dress). Practicality is always significant as it will make them feel comfortable. Working on site for an engineer may not permit her to wear traditional clothing or jilbab, as it also relates with on-site safety guidelines. Climate factors also contribute in selecting what to wear daily.

Accusing women who dress to impress may only be half true [6]. Most working women interviewed that dressing well makes them feels confident and professional, which boost their confidence level at work [7]. This may also be true as clothing relate closely with psychology that deals with feelings that keeps on changing every day and time. That is why; some scientist came out with color codes to make

\footnotetext{
${ }^{8}$ Protect their privet parts (from illegal sexual acts) and not to show off their adornment except only that which is apparent (like both eyes for necessity to see the way, or outer palms of hands or one eye or dress like veil, gloves, head-cover, apron, etc.) and to draw their veils all over Juyubihinna (i.e. their bodies, faces, necks, and bosoms, etc) and not to reveal their adornment except to their husbands, or their fathers, or their husband's fathers, or their sons, or their husband's sons, or their brothers, or their brother's sons, or their sister's sons, their (Muslim) women (i.e. their sisters in Islam) or the (female) slaves whom their right hands posses, or old male servants who lack vigour, or small children who have no sense of feminine $\operatorname{sex}$
} 
someone feel better at work according to their daily mood. Accusing men to be attracted solely to women physical look is also vague, as erotic differs from one culture to another [8].

Changes in women clothing nowadays indicate that the Malay had gone through vast social transformation from being domestic (housewife or mother) to professionals employee. Many modern Islamic scholars declared that working is permitted in today's context in most parts of the world, but very few debates on how working women should dress. Most Islamic scholars still refers to the rigid form of jilbab (outer garments) that shouldn't be changed; but how could it not evolves whereby other culture systems such as social, political, technology, arts and economy had changed tremendously? Clothing-as a culture object will always trail by changes in the socio-culture system, which may differ from one country to another. Being biased in interpreting the Al-Quran or hadith within the perception of the Middle-eastern culture is unjust to other societies who encompass different ideas and action in their daily life style.

For example, some rigid Islamic scholars prohibited women to use trouser as it displays the opposite gender. But the reality is that, fashion nowadays had developed many types of trouser specifically designed for woman. Specific feminine cutting such as palazzo with various prints and colors may look awkward for men to wear. Thus, fashion had differentiate the two genders by using various elements of design (i.e.: color, shape, form, texture, etc), so it is unjust to state that trousers are designed solely for men. This justification does not only apply to trousers as there is also other types of clothing such as jacket, t-shirt, and jeans that are made differently for each gender. In the Malay culture, uses of sarong can be seen on both sexes. Specific design elements are used to differentiate the gender. Principally, it is unfair to mention that certain types of piece/ design are made only for certain gender as each culture may perceive it differently.

Revealing the face and hands are not permitted in some Middle Eastern setting ${ }^{9}$, which may respond to situation where men (especially during the age of ignorance) perceives women as sexual object. This makes it appropriate for women at that particular cultural setting to cover their entire body (including face and palms) as they always became the target of sexual harassment ${ }^{10}$. In Malay Peninsula (and many parts of the Malay Archipelago) women once used sarong to cover their body until clothing was introduced through trade relation with China in the early 1400s, mainly for royal family [9]. Introduction on clothing to ordinary people came a bit later, as clothing was not affordable by many. This shows that, wearing clothing does not mean to attract the opposite sex as mentioned in Flugel's theory, whereby it varies from one culture to another.

The change in the social, religion and political system of

\footnotetext{
9 According to Salafist (Salaf means predecessors" or "ancestors) movement, covering the whole body with abaya (long dress/cloak) and niqab (face covering except the eyes) is a must.(Moosa, 2005) p.21

${ }^{10}$ During the ignorance age the position of the women was very degrading in the Arab society. They were treated as chattels and with contempt. The birth of a female child was considered as a great curse and she was often buried alive by the heartless father. Source: http://peacedeen.wordpress.com/2012/04/21/the-pre-islamic-period-jahiliya h-the-period-of-ignorance/ (30.10.13)
}

the Malay Peninsula had changed the way women dressed (refer Fig. 4a)-b)). The traditional dressed evolves until the Malays developed their own traditional attire called baju Melayu or baju kurung/ baju kurung Teluk Belanga (refer Fig. 4c)) which started by the royalties [10].

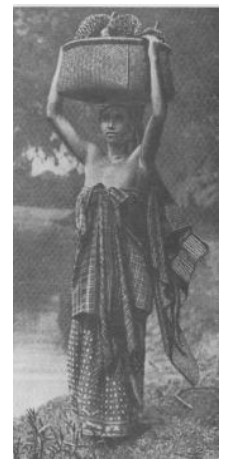

a)

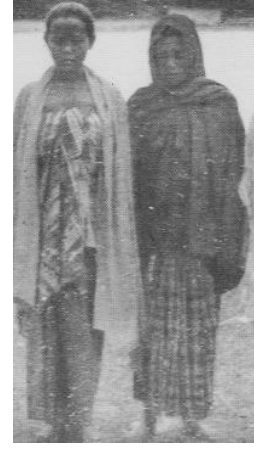

b)

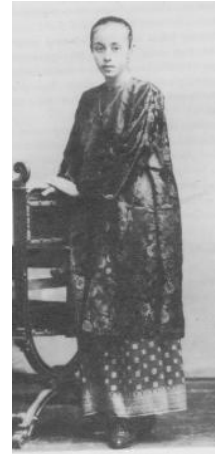

Fig. 4a). Women with just sarong with 'kemban' technique. Source:(Z.Syawal, 1994). b). Women started to use extra piece of sarong to cover their hair. Source: (Z. Syawal, 1994). c). A proper traditional baju kurung developed and use by women until today. Source: (Z. Syawal, 1994).

Nowadays, clothing for women has becoming more complicated rather than just a body covering. Clothing is a mixture between religion and modesty; gaining self-confidence, exhibit professionalism, culture, identity, social status and many more which added values to contemporary clothing. New values created by Malay women in Malaysia (at least to those who belong with the same group of respondents) showed that Islamic clothing is a concept that can be interpreted in many styles. Some may follow the basic guidelines in total without any amendment ${ }^{11}$, but most women understand that the guidelines can be interpreted with their own style. Being moderately dressed is the best as Islam wants their followers to look humble, not arrogant. Observation on Muslim women clothing reveals that most Malay women who practice Islam in their lifestyle follow the guidelines with various interpretations. (Refer Fig. 5a)-c))

Wearing Islamic mode does not have to be ugly, boring and dull as mentioned in many Islamic books. This may refer to the past Arab culture when women are merely sex object especially during the ignorance period. This may contribute to stricter rules in women's clothing, for that particular time and culture. This is when Allah request through His messenger Muhammad (Pbuh) that women must cover their entire body as a form of protection and identity as decent Muslim women ${ }^{12}$. As culture and time had changed the way men perceive women, new development of cultural object had slowly taking place to ensemble current lifestyle and setting but still within the context of Islamic guiding principles.

11 Salafist women prefer displaying themselves like in what their descendents did, which is covering the whole body except their eyes.(Yarwood, 1978)

${ }^{12}$ Fakhr ad-Din ar-Razi (d. 606): 'In the days of Jahiliyyah (pre-Islamic times) the free and women in bondage would go out uncovered and they would be followed by those intent on fornication and consequently allegations would be levelled against them. So that is why God ordered the free women to wear the jilbab.' [8] Source: http://www.khilafah.com/index.php/the-khilafah/social-system/576-jilbab-a nd-the-muslim-womans-dress-code (31.10.13) 


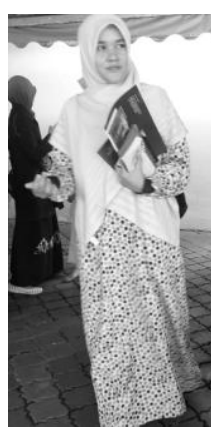

a)

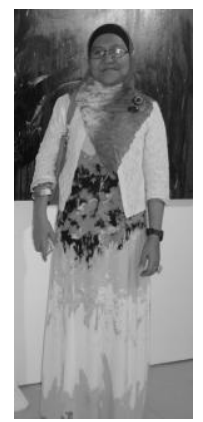

b)

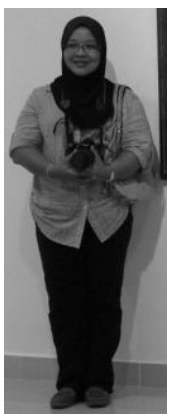

c)
Fig. 5a). Wearing abbaya/ jubah style. b). A more modern style; a dress with a jacket to cover the bust instead of shawl doing the part. c). Having loose blouse and pants. Compromising on length of the sleeves as they believe, by taking ablution water (wudu') may wash away the sin on the exposed hands (as stated by Humran ${ }^{13}$ ).

Many women do dressed up today as to please their own self, desire, comfort, profession and many more reasons. Dressing up to attract men is maybe half true; as men too have different reasons to be attracted to a woman, not necessarily via sexual appeal ${ }^{14}$. Random survey reveals that, women can be perceived attractive in many ways, such as attitude, grace, voice and many more regardless of appearance. That is why, in the holy book of Al-Quran, indicated that women must behave well in public (especially when there is presence of men), so that they might not be the attention of men. Dressing modestly must also come with being humbly in public ${ }^{15}$.

\section{CONCLUSION}

Basically, the Malay women in Malaysia understand the concept of Islamic clothing as stated in Al-Quran and hadith. Respondents who understand the concept of Islamic clothing adapted well with modern modes which very much related to faith. It is appropriate to judge someone who wears clothing according to the guidelines provided for Muslim are likely to practice all the principles of Islam in her daily life. Clothing is not only to cover one's body but clothing can also be an indicator of one's adherence to Islamic teachings.

Cultural object such as clothing will transformed once the people's perception and society had changed. Clash between modesty and display will always be a mover in fashion that

\footnotetext{
${ }^{13}$ Uthman said, "I am going to tell you a Hadith which I would not have told you, had I not been compelled by a certain Holy Verse (the sub narrator 'Urwa said: This verse is: "Verily, those who conceal the clear signs and the guidance which we have sent down...)" (2:159). I heard the Prophet saying, 'If a man performs ablution perfectly and then offers the compulsory congregational prayer, Allah will forgive his sins committed between that (prayer) and the (next) prayer till he offers it. Source: http://www.islamawareness.net/Wudu/sahih_bukhari.html

${ }^{14}$ Interviewed conducted on 20 Malay men, basically educated professional with moderate to good Islamic background revealed that men may be attracted to women due to many factors such as attitude, way of thinking, intelligence level, etc. Sexy clothing is indeed appealing but not to all men. Most regards them as cheap and immoral. Conclusion by many theories that stated all men are attracted to women's sexy body via clothing offended the respondents interviewed.

${ }^{15}$ Many phrases in the holy Quran gave examples on restriction or women, not only via clothing but many others such as socializing via talking, walking and appearance. Any act of interacting with men that has intention to attract them is prohibited (such as showing physical moves to impress men, making sexy voices, etc).
}

keeps on reinterpreting the guidelines given. The changes in Malay clothing from traditional to modern clothing shows that Muslim women in Malaysia had added new values in their overall appearance such as personal style (no longer collective like the past), flexible, adaptive and smart looking. These changes should not be interpreted as demolishing the Malay image or going against Islamic teaching; but one should perceive it as enhancing our cultural object to a better level.

Fashion evolution does not stopped here, as style in women's fashion kept on changing swiftly. Changes in design and style are evidence of transformation that happened in all culture including the Malays. Styling and tolerating with Islamic guideline shows that the Malay women in Malaysia are flexible, adaptive and fashionable. Through observations, there are many types of fashion used by the Malay women, some follow the guideline rigidly, but many do ignore them. Nevertheless, Islamic fashion will be continuously evolves as it indicates social and cultural transformation that enhances visual appearance of Malay women in Malaysia.

\section{ACKNOWLEDGMENT}

Special thanks to all respondents who spent their time for the interview: Rosemawati Md Noah, Norhayati Md Zain and Izatul Laili Jabar.

\section{REFERENCES}

[1] Koentjarningrat, Pengantar Ilmu Antropologi, Jakarta: PT Renaka Cipta, 2002, pp. 206-207.

[2] F. Davis, Fashion, Culture and Identity, Chicago and London: The University of Chicago Press,1992, pp. 82.

[3] Y. Yusuf, Studi Melayu (Malay Study), Jakarta: Wedatama Widya Sastra, 2009, pp. 106-111.

[4] A. Giddens, Living in A Post-Traditional Society/ Masyarakat Post-Tradisional, Cambridge/ Yogyakarta: 1994/2003, pp. 177.

[5] D. Yarwood, The Encyclopedia of World Costume, New York: Bonanza Books,1978, pp. 9.

[6] J. C. Flugel, The Psycology of Clothes, London: Hogarth Press, 1930, pp. $25-26$.

[7] M. Barnard, Fashion As Communication/Fashion Sebagai Komunikasi,Yogyakarta: Routledge, Jalasutra,1996, pp. 84-85.

[8] F. Davis, Fashion, Culture and Identity, Chicago and London: The University of Chicago Press, 1992, pp. 85.

[9] W. Groeneveldt, Nusantara Dalam Catatan Tionghua/ Notes on The Malay Archepelago and Malacca Compiled from Chinese Sources, Jakarta/London: Komunitas Bambu, 2009, pp. 182-185.

[10] S. Z. Ismail, Pakaian Cara Melayu, Bangi: UKM, 2009, pp. 179-180.

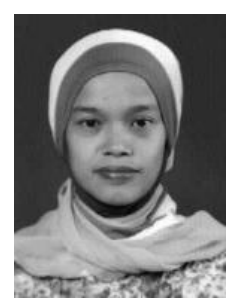

Hanisa Hassan was born in Kuala Lumpur on October 1,1974 . She obtained her first degree in fashion design from Mara Institute of Technology (ITM) Malaysia in 1996. After working as an automotive textile designer for a few years, she decided to continue her MA in 1999. She graduated with a PGD and MA in 2001 from Mara University of Technology (UiTM) in Malaysia in collaboration with de Montfort University Leister, UK. She had worked in various art and design institutions across Malaysia such as ASWARA, UiTM, CENFAD, University Malaya, The One Academy and head the School of Fashion and Textile at Legenda Education Group, before joining as an academic staff at Univeristi Malaysia Kelantan (UMK), Malaysia. She is now pursuing her PhD at Bandung Institute of Technology (ITB) Indonesia, conducting a research on new values in Malay women's clothing. 


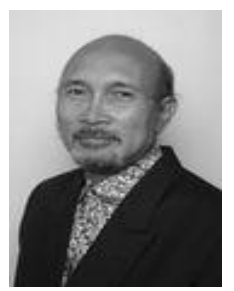

Biranul Anas Zaman was an alumni of ITB, graduated on BA in Fashion and Textile in 1978. Later, he joined Fulbright as research fellow at the Department of Anthropology, University of California, Berkeley USA in 2000. He then obtained a Doctoral degree from ITB in 2005.

He had written more than 30 journals, nearly 20 publications, mostly relating to traditional textiles of Indonesia. He also held almost 50 textile exhibitions of his work all over the world such as Korea, Japan, UK, Poland, Australia, Africa, Malaysia, Indonesia and many more.

Prof. Biranul was the dean of Faculty of Art and Design ITB from 2006-2010. After he had retired from ITB, he joined University of Computer Indonesia (UNIKOM) in Bandung, as the dean of the Faculty of Design in 2013 till now, but he still attaches with ITB as a guest professor. Prof. Biranul is also currently supervising Hanisa in her dissertation.

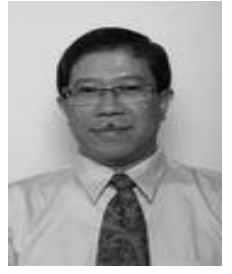

Imam Santosa was born on December 17, 1964 in Bandung, Indonesia. He obtained his 1st degree BA in 1988, majoring in interior design. He had his MA in design (interior) in 1994 and $\mathrm{PhD}$ in art and design in 2006. All degrees were taken at Institut Teknologi Bandung (ITB), Indonesia.

He had written about 10 research articles in journals. As a professional interior designer, he had done more than 12 professional design interior projects for government agencies and private companies.

Dr. Imam is currently heading the Faculty of Art and Design in ITB since 2012 to date. He also supervises Hanisa in her current dissertation. 